\title{
Erratum to: Ethics of calculation
}

\author{
Karamjit S. Gill
}

Published online: 23 February 2010

(C) Springer-Verlag London Limited 2010

Erratum to: AI \& Soc

DOI 10.1007/s00146-010-0266-6

Unfortunately, an error occured in line 62. The sentence should read:

Durbin reflects on the widening ethical role of the professional activist.

The online version of the original article can be found under doi:10.1007/s00146-010-0266-6.

K. S. Gill ( ()

Newport School of Art, Media and Design,

University of Wales, Newport PO Box 179,

Newport NP18 3YG, UK

e-mail: kgillbton@yahoo.co.uk 